\title{
The educational theorists, the teachers, and their history of education
}

\author{
Casale, Rita
}

\begin{abstract}
The following contribution expands the current discussion on the status and function of the history of education at the methodological, or epistemological, level by introducing the perspective of a history of educational knowledge. This opens up a theoretical option for educational historiography that avoids the identification of history of education with history of a discipline, or the institutionalized knowledge of education and teaching. As a consequence, some history of education topoi - as the history of a discipline - can be called into question and practiced historically rather than educationally or morally
\end{abstract}

DOI: https://doi.org/10.1007/s11217-004-4451-2

Posted at the Zurich Open Repository and Archive, University of Zurich

ZORA URL: https://doi.org/10.5167/uzh-156041

Journal Article

Published Version

Originally published at:

Casale, Rita (2004). The educational theorists, the teachers, and their history of education. Studies in Philosophy Education, 23(5-6):393-408.

DOI: https://doi.org/10.1007/s11217-004-4451-2 
RITA CASALE

THE EDUCATIONAL THEORISTS, THE TEACHERS, AND THEIR HISTORY OF EDUCATION

\author{
A plea for a history of educational knowledge
}

\begin{abstract}
The following contribution expands the current discussion on the status and function of the history of education at the methodological, or epistemological, level by introducing the perspective of a history of educational knowledge. This opens up a theoretical option for educational historiography that avoids the identification of history of education with history of a discipline, or the institutionalized knowledge of education and teaching. As a consequence, some history of education topoi - as the history of a discipline - can be called into question and practiced historically rather than educationally or morally.
\end{abstract}

KEY WORDS: history of education, history of ideas, history of knowledge, history of science, teacher education

\title{
INTRODUCTORY REMARKS
}

Since 1996, a remarkable debate has been going on in the journal Paedagogica Historica ${ }^{1}$ over the relation of educational historiography to so-called postmodernism and the educational function of a history of education. Using the pair of concepts "history of science" and "history of knowledge," I will address on a methodological, or epistemological, level the problems that are left open in the discussion on the educational function of the history of education in postmodern society. However, I find the trendy concept of

\footnotetext{
${ }^{1}$ See especially Paedagogica Historica XXXII (2) 1996, Paedagogica Historica XXXV (2) 1999, Paedagogica Historica XXXV (2) 1996, and Paedagogica Historica XXXVII (3) 2002. I will also refer to some contributions to the topic that appeared in History of Education 2, 2003 and History of Education. 28/1, 1999.
}

Studies in Philosophy and Education 23: 393-408, 2004.

(C) 2004 Kluwer Academic Publishers. Printed in the Netherlands. 
postmodernism $^{2}$ too vague a basis and the idea of context, as postmodernism terms it, inadequate. Instead, I will examine some considerations - Skinner's concept of the history of ideas and Foucault's history of knowledge - that have occupied historians and, in part, philosophers for the last thirty years and that may be significant for the historiography of education. On this basis, I believe that I can show the extent to which, first, the history of education should not be viewed as identical with the history of a discipline, or the institutionalized knowledge of education and teaching; second, that some of its topoi (such as established periodizations, ${ }^{3}$ national canons, ${ }^{4}$ classical works and "great men" ${ }^{5}$ and the distinction between formal and non-formal education) should be called into question; and, third, that the history of education should be formulated and practiced historically, and not educationally or morally.

\section{THE RENAISSANCE OF THE HISTORY OF EDUCATION AND ITS EDUCATIONAL FUNCTION ${ }^{6}$}

Historians of education agree that the history of education has enjoyed a Renaissance since the 1960s. There is less agreement, how-

\footnotetext{
${ }^{2}$ The juxtapositioning of modernism, as the period of the great meta-narrative, and postmodernism, as the period of the fragmentary and the narrative, is based on an exorbitant historical fallacy. From the postmodern perspective, however, there is a huge meta-narrative on the modern period that historical research would do well to dispense with. To note just one problem with this juxtaposition, I would like to mention the relation of the fragmentary to processes of longue durée. Should in fact postmodern historiography refer only to the fragmentary, it would no longer be in a position to explain the durability of semantics and historical processes. For so-called postmodernist theorists, some specific contemporary forms of social experience (like flexibility, discontinuity in way of life, fragmentation of biographies) are transformed directly into epistemological criteria of historiography. It appears, however, that the debate over modern and postmodern has lost some of its fashionable explosive power, and the tone of the discussion has become milder. We are therefore in an excellent situation to lead a scientific discussion on educational historiography since the crisis of humanistic historiography.

${ }^{3}$ See here J. Oelkers' study (1996) on the historiography of progressive education as a history of dogmas.

${ }^{4}$ Compare Daniel Tröhler's contribution to the present issue and R. Horlacher (2003).

${ }^{5}$ See here Andresen (2003).

${ }^{6}$ I thank Daniel Tröhler for his suggestions and for providing bibliographical references.
} 
ever, over the reasons for this new interest in historiography. And when it comes to its scientific status and consequent function, there is controversy.

While it is not difficult to note the success of educational historiography in the face of the numerous debates in various educational journals on its status and its function, the founding of some new journals focusing on the "History of Education" and, particularly, the high volume of history of education studies being published, ${ }^{7}$ some hermeneutic efforts are required as to the contextualization of this renewed interest in historically-oriented educational research. Some educational theorists, like Jürgen Herbst, see a connection between the success of educational historiography in the 1960s and 1970s and societal changes at the time, mainly the emergence of new political subjects. The women's and labor movements on the one hand, and continually increasing migration and mobility of the population at the international level on the other hand, seem to have contributed towards the rediscovery of the history of education and expanded it to encompass new topics. The history of women, the family, cultural and ethnic minorities, and social movements represent new fields of investigation in historical research (Herbst, 1999, p. 739). At first glance, Herbst appears to want to conduct the history of education in the sense of cultural studies, in that he places central importance on the political categories of race, gender, and class. In fact, however, this is a sociological extension of the history of education that has not fully considered the methodological and theoretical consequences of a cultural studies shift in the historiography of education.

Other educational theorists focus their educational historiographical considerations on the relation between the new social history of education of the 1960s, the new cultural history of education of the 1980s, social transformations, and epistemological changes in traditional historiography (see, for example, Cohen and Depaepe, 1996; Escolano, 1996; Lowe, 1996; Rousmaniere, 1996).

These two attitudes towards educational historiography and its success are revealed in the theorists' assessments of the consequences of that success and in the directions that they set. While some work towards a new history of education, others are committed towards a social history of the science of education, where the main interest is the linking of theory and practice.

\footnotetext{
${ }^{7}$ For an overview of the new map of educational historiography, see Tenorth (2003) and Depaepe (2001).
} 
In a 1996 special issue of Paedagogica Historica (1996/32), which was devoted to the topic of the history of education's responses to postmodernism, Heinz-Elmar Tenorth already raises a critical voice. He criticizes the consequences of the theorizing in the history of education in the last thirty years of the twentieth century and takes a clear position in support of the professionalization of educational historical research (Tenorth, 1996). Tenorth writes that the renunciation of educational self-interpretations and the methodizing and theorizing of educational historiography of the last 30 years have resulted not only in abandonment of the old topoi of the discipline, but also of the historically handed-down unity of reflection and practice, theory and action, and historical and contemporary consciousness of the educational task (ibid, p. 346). The history of ideas and discourse-analytical analysis, says Tenorth, have led historical research in the field of education to lose its orientating function, in that the former "history-izes" utopias and norms and thus relativizes them, and the latter, especially in Foucault's version, questions the value of modern institutions.

Three years after Tenorth's ambivalent assessment of the success of historical research, Jurgen Herbst called for a reinvigoration of the lost sense of educational orientation (Herbst, 1999). In an article on the "State of the art of the history of education," Herbst sees a potential for a new educational function of historiographical research by making it an essential component of teacher education and training. ${ }^{8}$ With this, Herbst steers the whole debate over the type and status of educational historiography to the question of the audience, or the imagined audience. In other words, the assumed need for orientation on the part of teachers - understood here as educational practitioners, not educational theorists - now becomes the criterion of a practice-relevant history of education. ${ }^{9}$

One of the consequences of concentrating the historiographical debate on the possible audience of the history of education is the rehabilitation of a genre that discourse-analytical historical research

\footnotetext{
${ }^{8}$ Other aspects of Herbst's argumentation are not discussed here. Herbst sees professionalization of the history of education as an alternative to the historical revisionism of the 1980s and 1990s, which he holds responsible for the decline of interest in educational historiography of the 1960s and 1970s.

9 In response to Herbst's call, a number of critical interventions followed, in which another criterion of the professionalization of educational historiography - namely, professional knowledge transfer - was proposed (see, among others, Marc Depaepe, 2001).
} 
had criticized strongly: the history of the classic figures and texts of education. Virtually untouched by the deconstruction of social scientific historiography, these "great men" of educational history and their works have become topical once again. The only effect of the debates on authors and texts, on inter-contextuality and inter-disciplinarity, on national stereotyping in historiography, and on the dominance of patriarchical models appears to be that the roster of great names has been expanded to include some generally recognized figures from other disciplines and other countries, as well as a few women. The justification for this revival of the most typical form of historiography in the social sciences is probably the special importance of the audience for educational historiography (compare Tenorth, 2003, p. 10). The great figures serve as educational role models who reconcile theory and practice in the desired way. They serve teachers as a reservoir of theoretical and practical aids, if not definitive solutions, writes Tenorth (ibid., p. 12): the great figures in education symbolize and represent educational tasks that must always be fulfilled anew and problems in educational theory in which the construction of the task and the hypothesized solutions must always be researched anew. Therefore, they document the stocks of problems and tasks upon which educational theory research and educational practice live (Tenorth, 2003, p. 12).

If we took the logic of this argumentation to the bitter end, we would have to ask ourselves who comes first when it comes to the determining function, teachers or the history of education? If the history of education is supposed to have an orientating function, then the problem can be solved only through scientific clarification of what should be regarded as adequate teacher education. However, the fact that the contemporary body of teachers, teachers whose education and training still stands within a humanities tradition, cannot be the starting point for a new definition of educational historiography is rather obvious, in my opinion, unless one has a liking for vicious circles.

The way out of the circulus vitiosus of the current discussion on the relation of teachers to the history of education requires, I believe, a further step - one which calls into question the identification of the history of education with the history of educational science as a discipline that is implied in the debate sketched out above.

Attempts to problematize the historiography of education must not refer exclusively to the topics, people, and aspects of the discipline. The result of that posture is in no way positive for consolida- 
tion of the discipline as compared to other scientific fields. In fact, subsuming theoretical considerations under moral or practical tasks results in a loss of scientific credibility. Educational scientists should ask themselves with a portion of irony what legal historian or what philosopher, to name two scientifically established disciplines, would think that the history of law should be written for lawyers alone, or the history of philosophy for philosophy teachers only? Even worse, what legal historian or philosopher would think that someone other than a jurist, or philosopher, should write the scientific history of law or philosophy? ${ }^{10}$

I believe that one of the problems of the self-definition of the discipline of educational science lies in the understanding of its relation to theory and practice and in the relation of theory and practice.

In the following section, I turn to a clarification of the relation of theory and practice before making an attempt at an initial definition of the history of educational knowledge.

\section{THE PRACTICE OF THEORY AND THE THEORY OF PRACTICE}

Focusing on the teacher or educator as the addressee of educational considerations and historical research presupposes a clear separation between theory and practice. According to this view, educational scientists find educational legitimization only if they refer to the practice of their audience, and teachers and educators ground their practice in science only when they are guided by theory and by historical role models.

Some theoretical considerations that have been developed in the very area of historiography have pointed out the artificiality of this separation of theory and practice and emphasized the performative character of theory, or the material productivity of knowledge. I will refer to only two treatments of this problem, which I find representative of the broader field of discussion in historical semantics: ${ }^{11}$

\footnotetext{
${ }^{10}$ To take Germany as an example, the unfortunate consequences of such an attitude is revealed by the fact that, for instance, there exists no Max-Planck Institute of the history of education.

${ }^{11}$ For an overview of the different forms of historical semantics (history of terms, history of discourse, and history of metaphors), see Bödeker, 2002.
} 
Quentin Skinner on the performative function of language and Michel Foucault on "discursive practice".

With no intention of overlooking differences between Skinner's version of the history of ideas and Foucault's discourse analysis, my interest here is to point out the significance for the historiography of education of their reflections on the pragmatic emergence of theories and the linguistic codifications of practitioners.

Skinner's notion of performative language refers to the practical effect of statements. ${ }^{12}$ The background of this view of language is a bow to its realistic task. Language does not have to reflect reality; instead, it produces reality with its utterances. This performative feature of language should not be confused with the poietic power of the idea as conceived by the idealists. It is not about deriving reality from a theory, from reason, or from an idea. It is about the rhetorical power of language. We say things, not in order to explain the facts of a phenomenon, but in order to push through a particular interpretation of that phenomenon. In this sense, we are always doing something as well as saying something. We say things in order to make possible a particular effect. The relation between utterances and their effects is not, however, causal in nature. But this in no way excludes the intentional character of speech acts.

Following Austin's (1962) and Searle's (1969) investigations of the uses as opposed to the meanings of words, Skinner develops a theory of historical interpretation that sees itself as contextualization of the effects of speech acts. Authors of classic texts are no longer interpreted on the basis of their contributions to the perennial issues and problems within a discipline. Instead, the effect of their writings is viewed as to the context in which they emerged and measured according to their semantic change. In both cases, intellectual context and semantic changes, the meaning and effect of the speech act are explained by looking at the things that speech acts can do in and by the use ${ }^{13}$ of language and their rational paradigm. Use and rational paradigm of a speech act delimit the sphere of what, at any particular time, is held to be true. To this belong forms of belief, customs, and

\footnotetext{
${ }^{12}$ My analysis of Skinner's performative character of language bases on a volume by Skinner on historical interpretation that was published in Italian (Skinner, 2001).

${ }^{13}$ Use is used by Skinner following Wittgenstein's considerations in his later writings, particularly Philosophical Investigations (Wittgenstein, 1958, paragr. 11, p. 546)
} 
conventions that in a particular context allow speech acts to appear credible.

Here, the impossibility of distinguishing between theory and practice shows up in two ways. First, theories and interpretations have effects in that they reproduce, institutionalize, canonize or change certain traditions, manners, and customs. Second, theories are always dependent upon the social and political context.

Following Skinner's considerations, educational theory and educational practice can no longer be strictly separated. It seems to make even less sense to differentiate between the history of ideas of education and its social history (compare Oelkers, 2001).

Whereas Skinner's historical interpretation of the performative character of language refers to the intentions or ideas of the author, Foucault's analysis of the language of practices, institutions, and scientific codifications applies to utterances whose performative character does not rest upon the author's intentions, but on the epistemological role that they play in a defined historical and scientific context. It is not the author who determines the intention of his writings. They gain their meanings directly from the locations (institution, discipline, manners) at which they are uttered. The subject of Foucault's analysis is not the history of theories or the history of ideas, but the way in which scientific discourse is practiced, or regimes of practices (Foucault, 1969, p. 81).

Far from being two, separate spheres, theory and practice are two sides of the same coin. To put it more simply with regard to educational practice and theory, we could say that every teacher or educator acts knowingly, and every historian of education researches actively. Both of these activities, educational research and educational action are, to follow Foucault's argument, determined by the same rules that determine their context. As Foucault explains, he tries to grasp scientific discourse not from the point of view of the speaking individuals and not from the perspective of the formal structures that determine what they say, but rather from the perspective of the rules that are important for the sheer existence of this discourse (Foucault, 1970, p. 15).

Although Skinner's history of ideas also allows deconstruction of social scientific historiography and its topoi, it still remains bound to the great figures of history whose ideas it attempts to contextualize. In contrast, Foucault's history of the practices of knowledge opens up the possibility of a history without great figures. Foucault rejects the practice of relating a piece of discourse to 
its specific author. It is not the great authors that should stand at the center, but rather the locations, contexts, in which individuals have practiced certain forms of knowledge. ${ }^{14}$ Foucault writes that when we attempt to examine discursive networks or epistemological fields that encompass a (simultaneous or successive) plurality of concepts and theories, it becomes evident that attribution to one individual is impossible. Likewise, the analysis of the transformations can hardly be attributed to a particular individual. This is because the transformation generally takes place through the works of various individuals; it is not a discovery, an assertion, or a clearly formulated thought that is explicit within a single work. Instead, transformation can be established if we look for it as something that occurred in a number of various texts" (Foucault, 1969, p. 74).

Whether and how a history of education can be written without the classic texts and without education's "great men" and also "great women" is a question that only a future generation of educational historians can answer.

Neither Skinner nor Foucault can be said to dispense with the normativity of action. Rather, we are dealing here with a pragmatic modification of the rational (see Schneider, 2003, p. 225), which may be eminently suitable for the historiography of a social science like the history of education.

From the perspective of the relation of theory and practice, it is clear that definition of the status and type of educational historiography is confronted with a number of theoretical problems, particularly with regard to the object of and the type of historiography of education. How can these problems be approached? If we are to solve them within the perspective of the discipline and its traditional consolidation using national canons and established role models, then we will have to deal with the history of the science of educational science, with the history of its institutions and its topoi. If we attempt to cross the confines of the handed-down discourse on education, however, this will mean turning to the history of educational knowledge and its locations and institutions. In that case, the issue is not only the content of the history of education, but the concept of education itself.

\footnotetext{
${ }^{14}$ On the differences between Skinner's and Foucault's historiography, see Keane (1995).
} 


\section{HISTORY OF KNOWLEDGE OR HISTORY OF SCIENCE}

At the risk of simplicity, a short and pithy definition of the difference between a history of knowledge and a history of science could be the following: history of knowledge refers to theoretical objects, while history of science refers to forms and locations in which and at which scientific objects are captured. In this view, history of knowledge is the history of epistemological changes or, to follow Kuhn, shifts in scientific paradigms, or, in traditional terms, the history of ideas. The history of science is the history of academic disciplines (including their canonized knowledge) and the institutions that control access to the various scientific objects.

Faced with these two possible ways of conducting historical research and representing historical material, historians of education behave rather one-sidedly. Educational theorists make a plea for and practice in the main a history of science, or more precisely, a history of their discipline. Even in cases where educational theorists deal de facto with the history of knowledge in their discipline, they do this from the perspective of the discipline and not from that of the object of knowledge. Histories of educational epochs or histories of the classic authors, however, ultimately serve only to confirm a particular history of the discipline and its institutionalization.

This stance, however, should not be seen simply as an unreflected but widespread practice, as if to say that educational theorists were reproducing a particular historiography without being aware of the type of historical research they were conducting. The fact is that educational theorists utilize various theoretical approaches consciously to defend the decision to practice the history of education as the history of a discipline, or as history of science.

The intentional reproduction of a particular historiography on the part of educational theorists can be shown by taking the example of the current debate on professionalization of the history of education that I mentioned above.

In disregard of the results of thirty years of methodological debate among historians about how history should be written in the wake of the so-called linguistic turn or the crisis of the humanistic approach (see Bödeker, 2002; Sarasin, 2003, p. 10-60), educational theorists settle for a Renaissance of the history of education that is determined educationally insofar as it is directed to a target group. The central issue for educational historians is: Who should read the history of 
education? This special way of subjectivizing historiography is defended in the name of professionalizing historical research. The "who" of the history of education is no longer the historian (the author) or the hero of the discipline, but rather the audience. This focusing of educational historiography on the target group has become so dominant that some educational theorists have even called for a strict separation between a history of education that is written by educational theorists for educators and a history of education that is written by historians (compare here William Richardson, 1999). ${ }^{15}$ It is not difficult to imagine the consequences such a division would have on the discipline. At the level of scientific comparison and competition with other disciplines, the history of education would isolate itself, and as to the education and training of teachers, it would bring up teachers who would teach and educate pupils using contents and role models of yesteryear.

Approaching the problem at an epistemological level, however, and attempting to contextualize education's preference for history of science, there are some historical remarks that can be made. They have to do with national construction, which stands behind the idea of history of science, and the cultural context in which it emerged. The prerequisite of history of science is the way that in the nineteenth-century Europe of nations, the science of history was instrumentalized for the purpose of consolidating national identity. ${ }^{16}$ History as a resurrection of the past becomes a national resource for the future, in that it brings a national past to life. Obviously, the process of scientifically establishing national identities affects not only educational science. The various sciences play very different roles in this context, depending upon their scientific prestige and their political significance. ${ }^{17}$ This idea of history as a resurrection of the past is supported by the bourgeoisie, which views political power and the institutions that have achieved it as the result of a historical process, of progress, that has reached its highest point and therefore, even if the power and institutions are not without ambivalence, should be maintained and protected.

\footnotetext{
15 Aldrich (2003) has criticized this rigid separation between history of "historians" and history of "educationists."

${ }^{16}$ It is not by accident that Micha Brumlik speaks of identity discourses when referring to the debate on classic figures and texts (Brumlik, 2000, p. 41).

17 On the role of the natural sciences in the constitution of national identities, see Jessen and Vogel (2002).
} 
Whereas the history of science accents tradition and continuity, the history of knowledge - both in the sense of Skinner's history of ideas ${ }^{18}$ and in the sense of Foucault's history of knowledge practices emphasizes changes, ruptures, semantic and conceptual changes, epistemic shifts. The educational function of a history of knowledge would lie in the transmission of experiences of change of historical processes. The motivation for a transition to a history of knowledge is not, however, for the sake of educational or moral purposes, but rather the historical understanding of the history of science, or histories of science, as a phenomenon of the nineteenth century. For an adequate historical analysis of the history of science would have to take three aspects into consideration: the relation between the different histories of science (relating to different disciplines), the relation between a discipline and the development of its institutions (school, academy, university, association), and the cultural traditions that have influenced the historiography of a discipline. As an analysis of this kind demands comparative investigation, it can hardly be conducted only from within the internal perspective of a discipline.

It is Foucault, who provided the most important contribution towards understanding the distinction between history of science and history of knowledge (see Foucault, 1969b). Following Foucault, the difference between knowledge and the various forms of knowledge is categorical in nature. Knowledge takes the form of an episteme and is anchored within a particular epoch. The episteme, or knowledge, presents the totality of relationships within which sciences and formalized systems obtain their meaning (see Foucault, 1969b, pp. 272273). For Foucault, independently of institutionalized differences between the various sciences, there is an order of discourse that is epistemological in nature and represents the transcendental in an epoch (see Casale, 2001 pp. 41-44). The historical character of the epistemes in Foucault is radically different from the original meaning of transcendental in Kant. Here, transcendental does not mean deep structure, but rather the relation between the different scientific statements: it is merely a description that deliberately refers to the surface (Foucault, 1973, p. 505).

\footnotetext{
${ }^{18}$ For Skinner, the difference between his own type of historiography and R. Koselleck's Begriffsgeschichte (conceptual history, as developed and practiced in Germany) is that Begriffsgeschichte is interested only in processes of longue durée. In contrast, Skinner's investigations focus upon changes in concepts (Skinner, 2001, p. 180).
} 
Despite this superficial determination of the episteme, it is difficult to understand it without thinking of a totality whose historicity and systematicity is very problematic (see Daston, 2003, p. 213). Foucault's concept of knowledge, or the episteme, suggests that an epoch has its own particular historical character. As Lorraine Daston has pointed out, the systematicity of epistemes implies the notion of an uninterrupted rhythm of history itself, the notion of fundamentally coherent periods, which are disrupted by dramatic turning points, for due to their nature, epistemes cannot change in a step-wise fashion (Daston, p. 213). Foucault's definition of episteme seems reminiscent of Hegel's redivivus, but minus Hegel's progress and minus teleology.

In the face of these objections, a revision of Foucault's concept of history of knowledge following Daston makes sense. The issue is no longer to link forms of knowledge to the sequence of uniform historical periods, but rather to seek their dependency upon objects, contexts, and locations. Daston points out that "spaces of knowledge" bring locations and boundaries into the picture. In these spaces, there are positions relative to one another, and there are also regions "outside" that do not belong. The nature of these spaces seems to be more Aristotelian than Euclidean or Newtonian (Daston, p. 215). The spaces of knowledge should correspond to the topics of the objects, the content, and not the sequence of periods in time.

Similarly, for a history of educational knowledge, I put the accent on the object, the substance, as that which should be investigated. Historical research should gain direction and specificity from educational phenomena, which must be viewed in their contextuality. This is an inter-disciplinary perspective, which should not lead to dissolution of the discipline. The history of education is aware that educational phenomena cannot be approached without consideration of theories, analyses, indications, and texts from other disciplines that have played a role in determining its varying contexts. Examination of the medical, moral, aesthetic, and literary context of an educational problem, for example, does not necessarily imply a loss of the specificity of the scientific approach if the direction of the perspective is guided by the educational object.

Expansion of the educational viewpoint from the perspective of the history of educational knowledge involves materials, time, and locations. Expanding and increasing the sources, times, and spaces is important not only historically. The inclusion of sources, times, and 
areas that have been excluded from the canonized history of education due to their supposed inconsequential role in the discipline also contributes towards putting in question conventional conceptions of the discipline. Ultimately, defining the status and function of the discipline is not concerned with the past and tradition; instead, it means determining the object, the substance, of the history of education.

No progress towards clarifying the problem will be made so long as examination of the function and status of the history of education remains an internal affair of the discipline, its survival, and its direct reference to teacher education and training.

Only a look from the outside can contribute to an understanding that the discipline's way of looking at things definitely has problematic, historical, and theoretical implications.

But a structural openness of the history of education to interdisciplinary comparison would allow it to develop a more accurate historical view of the discipline and its manner of proceeding and, perhaps, to achieve a new conceptual definition of the discipline.

\section{REFERENCES}

Aldrich, R. (2003). the three duties of the historian of education. History of Education, 2, 133-143.

Austin, J.L. (1962). How to do things with words. Cambridge, Mass.: Harvard Univ. Press.

Andresen, S. (2003). "Mit Vorsicht zu genießen”. Zur Semantik von Größe, Erziehertum und Männlichkeit um 1900. Manuscript Zürich.

Bödeker, H.E., Ed. (2002). Begriffsgeschichte, Diskursgeschichte und Metapherngeschichte. Wallstein Verlag: Göttingen.

Brumlik, M. (2000). Epizyklen. Ein Diskussionsbeitrag. Zeitschrift für pädagogische Historiographie, 2, 40-41.

Casale, R. (2001). Die Verwandlung der Philosophie in eine historische Diagnostik der Differenzen. In H. Lutz \& N. Wenning (Eds), Unterschiedlich verschieden (pp. 25-46). Opladen: Leske-Brudrich.

Cohen, S. \& Depaepe, M. (1996). History of education in the postmodern era. Introduction. Paedagogica Historica, 32, 301-305.

Daston, L. (2003). Gedankensysteme. Kommentar zu Arnold Davidson "Über Epistemologie und Archäologie. Von Canguillhem zu Foucault”. In A. Honneth \& M. Saar (Eds), Michel Foucault. Zwischenbilanz einer Rezeption. Frankfurter Foucault-Konferenz 2001 (pp. 212-219). Frankfurt am Main: Suhrkamp.

Depaepe, M. (2001). A professionally relevant history of education for teachers: Does it exist? Paedagogica Historica, 37, 631-640.

Escolano, A. (1996). Postmodernity or high modernity? Emerging approaches in the new history of education. Paedagogica Historica, 37, 324-341. 
Foucault, M. (1969a). Die Situation Cuviers in der Geschichte der Biologie (Vortrag). In M. Foucault (Ed), Dits et écrits. Schriften in vier Bänden, Bd. II: 19701975. Hrsg. Von Daniel Defert und François Ewald. Aus dem Französischen. Frankfurt am Main: Suhrkamp 2002, 37-82.

Foucault, M. (1969b). Archäologie des Wissens. Frankfurt am Main: Suhrkamp 1981.

Foucault, M. (1970). Vorwort zur englischen Ausgabe. In M. Foucault (Ed.), Schriften in vier Bänden. Bd. II, Frankfurt am Main: Suhrkamp 2002, 9-16.

Foucault, M. (1973). Von der Archäologie zur Dynastik. In M. Foucault (Ed), Schriften in vier Bänden. Bd. II, Frankfurt am Main: Suhrkamp 2002, 504-518.

Herbst, J. (1999). The history of education: State of the art at the turn of the century in Europe and North America. Paedagogica Historica, 35, 737-747.

Horlacher, R. (2003). Die Entpolitisierung des Bildungsbegriffs. Zeitschrift für pädagogische Historiographie, 1/2003, 39-43.

Jessen, R. \& Vogel, J. (2002). Wissenschaft und Nation in der europäischen Geschichte. Frankfurt am Main/New York.

Keane, J. (1995). The narrator and the archaelogist: Modes of meaning and discourse in Quentin Skinner and Michel Foucault. Statsvetenskapling Tidskript, 2141.

Lowe, R. (1996): Postmodernity and historian of education: A view from Britain. Paedagogica Historica, 32, 307-323.

Oelkers, J (1996). Reformpädagogik: eine kritische Dogmengeschichte. 3., vollst. bearb. und erw. Aufl. Weinheim: Juventa-Verlag.

Oelkers, J. (2001). Ein Essay über den schwindenden Sinn des Gegensatzes von "Ideengeschichte" und "Sozialgeschichte" in der pädagogischen Geschichtsschreibung. Zeitschrift für pädagogische Historiographie, 1/2001, 21-25.

Peim, N. (2001). The state of the art or the ruins of nostalgia? The problematics of subject identity, its objects, theoretical resources and practices. Paedagogica Historica, 37/3, 653-660.

Rousmaniere, K. (2001). Fresh thinking: Recent work in the history of education. response to Jürgen Herbst's state of the art article. Paedagogica Historica, 37/3, 649-652.

Richardson, W. (1999). Historians and educationists: The history of education as a field of study in post-war England. Part I: 1945-1972. History of Education. 28/1, 109-141.

Sarasin, Ph. (2003). Geschichtswissenschaft und Diskursanalyse. Frankfurt am Main: Suhrkamp.

Schneider, U.J. (2003). Wissensgeschichte nicht Wissenschaftsgeschichte. In A. Honneth \& M. Saar (Eds), Michel Foucault. Zwischenbilanz einer Rezeption. Frankfurter Foucault-Konferenz 2001 (pp. 220-229). Frankfurt am Main: Suhrkamp.

Searle, J.R. (1969). Speech acts. Cambridge: Cambridge University Press.

Skinner, Q. (2001). Dell'interpretazione. Bologna: il Mulino.

Tenorth, H.E. (1996). Lob des Handwerks, Kritik der Theorie. Zur Lage der pädagogischen Historiographie in Deutschland. Paedagogica Historica, 32, 343361. 
Tenorth, H.E. (2003). Klassiker in der Pädagogik - Gestalt und Funktion einer unentbehrlichen Gattung. In H.E. Tenorth (Ed.), Klassiker der Pädagogik. München: Beltz, pp. 9-20.

Wittgenstein, L. (1958). Philosophical investigations. Oxford: Blackwell.

Allgemeine Pädagogik

Pädagogisches Institut

Universität Zürich

8006 Zürich

Schweiz

E-mail: rcasale@paed.unizh.ch 